Global Business Research Congress, June 10-11, 2021

\title{
FORMATION OF INTERCULTURAL TOLERANCE ON PUPILS IN ENGLISH CLASSES
}

\author{
DOI: 10.17261/Pressacademia.2021.1440
}

PAP- V.13-2021(29)-p.113

\section{Dilnoza Kurbonova Arslanovna}

Jizzakh Polytechnic Institute, Foreign Languages Department, Jizzakh city, Uzbekistan. dilnoza_kurbonova8386@mail.ru, ORCID: 0000-0001-9435-8975

\section{To cite this document}

Arslanovna, D.K., (2021). Formation of intercultural tolerance on pupils in English classes. PressAcademia Procedia (PAP), V.13, 113.

Permanent link to this document: http://doi.org/10.17261/Pressacademia.2021.1440

Copyright: Published by PressAcademia and limited licensed re-use rights only.

\begin{abstract}
Purpose-The purpose of this study is to highlight the pedagogical aspects of the formation of students ' competencies of intercultural tolerance in English lessons. In this article it is clearly shown the how important is the intercultural tolerance of pupils for the country and for the world.

Methodology-The study employs on investigation on some methods such as Role play, Game with different cultures, Forming the principle of tolerance in students, Questions and Discussion. They can help teachers to form intercultural competence on students in English classes. Findings-The analysis reveals that it is very relevant to form intercultural tolerance on school pupils and English class is effective in implementing it. By some methods which are used in investigation are considered to be very helpful in formation of intercultural tolerance on pupils.

Conclusion- based upon the analysis it may be concluded forming an intercultural tolerance on pupils in English classes is very relevant. And these methods can be used for forming intercultural tolerance on pupils in English classes as English classes are very good for making it and also these methods are helpful for improving language skills of pupils
\end{abstract}

Keywords: Tolerance, intercultural tolerance, pedagogical tolerance, cultural literacy, methods, theoretical methods JEL Codes: A10, A19

\section{REFERENCES}

Bada, E. (2000). Culture in ELT. Cukurova University Journal of Social Sciences, 100-110.

Bennett, W.J. (2001). The broken hearth. New York: Doubleday.

Bezotechestvo, L.M. (2015). Formation of tolerance in students - future teachers: vocational training in the university educational process: Ph.D. thesis. Krasnoyarsk: FSBEI HPE, KSPU named after V.P. Astafiev.

Dilnoza Kurbanova (2020). Pedagogical Opportunities for Formation of Intercultural Tolerance Competence in English Language Classes. International Journal of Business Education and Management (IJBEMS), 5(2).

Fitzgerald, M.H. (2000). Establishing cultural competency for mental health professionals. In: V. Skultans, and J. Cox (Eds.), Anthropological approaches to psychological medicine: Crossing Bridges, 184-201.

Von Bergen, C.W., Von Bergen, B.A., Stubblefield, C., and Bandow D. (2012). Authentic tolerance: between forbearance and acceptance. Journal of Cultural Diversity, 19(4), 111-117.

Kramsch, C. (1993). Context and culture in language teaching. Oxford: Oxford University Press.

Sadykova, A., Smirnova, E. (2014). Phraseological Units in Press: Cultural Peculiarities. Phraseology in Multilingual Society. Edited by Arsentieva E. Cambridge Scholars Publishing, 229-237.

Thanasoulas, D. (2001). The importance of teaching culture in the foreign language classroom. Radical Pedagogy, ICAAP.

T.Kh.Akbarov, U.B.Orunbaev, Problems of formation of tolerance in educational process. 2014-04-23 library.ziyonet.uz

Tucker, G.R. and Lambert, W.E. (1972). Sociocultural aspects of foreign-language study. In J.W. Dodge, (ed), Northeast Conference Reports. Montpellier, Vermont: The Capital City Press.

Valdes, J.M. (Ed.). (1986). Culture bound: bridging the cultural gap in language teaching. Cambridge: Cambridge University Press. 